Jurnal Media Pertanian, 5(1) April 2020, pp.1-5

Media Komunikasi Hasil Penelitian dan Review Literatur Bidang Ilmu Agronomi ISSN 2503-1279 (Print) | ISSN 2581-1606 (Online) | DOI 10.33087/jagro.v5i1.91

Publisher by : Program Studi Agroteknologi Fakultas Pertanian Universitas Batanghari

\title{
Daya Kecambah dan Kekuatan Tumbuh Benih Kakao (Theobroma cacao L.) pada Berbagai Media Simpan
}

\author{
${ }^{* 1}$ Yulistiati Nengsih, ${ }^{1}$ Yuza Defitri dan ${ }^{2}$ Trisna Levia \\ ${ }^{1}$ Program Studi Agroteknologi, Fakultas Pertanian Universitas Batanghari \\ ${ }^{2}$ Alumni Program Studi Agroteknologi, Fakultas Pertanian Universitas Batanghari \\ Jl. Slamet Riyadi-Broni-Jambi, 36122 Telp. +62074160103 \\ *1e-mail korespondensi: nyulistiati@yahoo.com
}

\begin{abstract}
Cocoa seeds are recalcitrant seeds that contain high water content that are sensitive to decreased viability to death if stored for long periods of time. The main problem in storing recalcitrant seeds is that they cannot be dried below the critical moisture content, are easy to germinate, and are not tolerant of low suhu, so that the right containers and media are needed to store the seeds. This study aims to obtain suitable media in storage of cacao (Theobroma cacao L.) seeds in maintaining seed viability. This study uses a completely randomized design (CRD) method with one treatment factor, namely the use of different storage media with 4 levels, namely (p1) sawdust media, (p2) cocopeat media, (p3) charcoal media at once, and (p4) powder media wood charcoal, each level was repeated 3 times so that there were 12 trial lots, each lot containing 40 cacao seeds with a total of 480 cacao seeds. Variables observed were: storage media water content, seed water content, percentage of seedling capacity in storage, moldy seed percentage, mushroom identification, percentage of seedling capacity, sprout length, and speed of contamination. To see the effect of the treatment carried out F test, then continued with Duncan test at $\alpha$ level of 5\%. The results showed that the treatment of rice husk charcoal media had a significant effect on the length of the sprouts and the speed of contamination after storage, and the fungus identified during storage was Aspergilus. spp.
\end{abstract}

Keywords: Recalcitrant, seed moisture content, viability.

\begin{abstract}
Abstrak.Benih kakao tergolong benih rekalsitran dengan kadar air tinggi dan peka terhadap penurunan kadar air. Daya tumbuh cepat menurun sampai benih tersebut mati dalam penyimpanan. Penurunan kadar air dibawah titik kritis merupakan masalah, benih mudah berkecambah, dan mati bila disimpan pada suhu rendah. Adanya media simpan yang baik diharapkan benih dapat disimpan lebih lama serta mempertahankan daya kecambah dan kekuatan tumbuh benih. Penelitian bertujuan mendapatkan media yang tepat untuk penyimpanan benih kakao dan secara bersamaan mempertahankan daya kecambah dan kekauatan tumbuhnya. Penelitian ini menggunakan metode Rancangan Acak Lengkap (RAL) dengan satu faktor perlakuan yaitu penggunaan media simpan yang berbeda dengan 4 jenis media yaitu serbuk gergaji $\left(\mathrm{p}_{1}\right)$, cocopeat $\left(\mathrm{p}_{2}\right)$, arang sekam padi $\left(\mathrm{p}_{3}\right)$, dan serbuk arang kayu $\left(\mathrm{p}_{4}\right)$, setiap jenis media diulang sebanyak 3 kali sehingga terdapat 12 petak percobaan yang masingmasing berisi 40 benih kakao. Peubah yang diamati adalah: kadar air media simpan, kadar air benih, persentase daya kecambah dalam penyimpanan, persentase benih berjamur, identifikasi jamur, persentase daya kecambah, kecepatan berkecambah, dan panjang kecambah. Data hasil pengamatan dianalisis dengan uji F dan dilanjutkan uji Duncan pada taraf $\alpha 5 \%$. Hasil penelitian menunjukkan bahwa media arang sekam padi dapat mempertahankan kualitas benih kakao dengan indikator benih berjamur selama 12 hari penyimpanan sebesar 0,92\%. Setelah 12 hari disimpan, daya kecambah sebesar 64,20\%, kecepatan berkecambah 2,1 etmal $^{-1}$,dan panjang kecambah 6,82 cm.Jamur yang teridentifikasi selama penyimpanan adalah jamur Aspergilus. spp.
\end{abstract}

Kata kunci : kadar air benih, rekalsitran, viabilitas,.

\section{PENDAHULUAN}

Kakao (Theobroma cacao L) merupakan salah satu komoditi yang memberikandevisa yang besar bagi negara yang menempati posisi nomor 3 setelah kelapasawit dan karet. Ditingkat pekebun, kakao merupakan sumber pendapatan yang penting, baik sebagai tanaman utama mau pun tanaman sela (Rahardjo, 2011).

Pembangunan kebun kakao untuk tanaman baru atau mengganti tanaman tua dan rusak terus dilakukan. Permintaan benih kakao yang akan digunakan sebagai batang bawah ataupun sebagai bibit generatif meningkat sejalan dengan perkembangan pembangunan kebun. Harga biji kakao kering di tingkat petani yang cukup bagus, mendorong pekebun untuk meningkatkan luas tanam dan melakukan peremajaan tanaman. Pembangunan kebun baru dan mengganti tanaman tua memerlukan benih kakao yang berkualitas dan mencukupi.

Benihkakao yang tergolong benih rekalsitran sehingga diperlukan kondisi penyimpanan yang dapat mempertahankan kadar air benih agar tidak turun di bawah titik kritisnya. Menurut Kustantini dan Kusumastuti (2015) bahwa mempertahankan kualitas benih saat memasuki masa simpan merupakan sesuatu yang penting sehingga benih dapat ditransportasikan dengan aman.Permasalahan penyimpanan benih kakao adalah kadar air nya tidak dapat diturunkan di bawah kadar air kritis, tidak toleran terhadap suhu rendah danmudah berkecambah Mempertahankan kualitas benih tetap prima saat benih tersebut akan disemaikan merupakan target dari penyimpanan benih. 
Pemilihan media penyimpanan yang tepat untuk mempertahankan kelembaban benih kakao selama penyimpanan merupakan upaya yang penting untuk mempertahankan daya berkecambah dan kekuatan tumbuh benih. MenurutSyaiful, Ishak, dan Jusriana(2007), serbuk gergaji, dan sekam padi merupakan media simpan yang tepat untukbenih rekalsitran.

Pelindung media penyimpanan juga memberikan pengaruh terhadap kualitas benih rekalsitran saat penyimpanan. Kardus bisa menjadi kemasan yang fungsional, murah, dan dapat didaur ulang. Kardus memberikan situasi yang tahan guncangan sehingga kondisi benih tetap aman (Klimchuk dan Krasovec 2006). Pengemasan juga berfungsi untuk menekan penguapan dan juga cukup untuk menahan kelembaban. Untuk itu kardus bahan pengemas sebaiknya berventilasi sehingga tercipta aerasi yang baik di sekitar benih. Menyimpan benih kakao tanpa aerasi dapat menurunkan kualitas benih. Hasil penelitian Nengsih (2018), menunjukkan bahwa benih kakao yang disimpan di dalam kardus berventilasi $8 \%$ dengan menggunakan media cocopeat dapat menahan serangan jamur 17,19\% selama 12 hari penyimpanan. Penggunaan kardus berventilasi $8 \%$ dengan media simpan cocopeat dapat mempertahankan viabilitas benih. Sumampau (2011) penggunaan media simpan serbuk gergaji dapat mempertahankan daya kecambah benih kakao sebesar 93,33\%. Menurut Raharjo (2012) penggunaan arang sekam padi dapat mempertahankan daya kecambah benih kakao 85 - 98\% dengan lama penyimpanan 3 minggu. Winiariyasti (2015), menyatakan bahwa benih kakao yang disimpan dengan menggunakan serbuk arang kayu mampu mempertahankan viabilitas benih selama 2 minggu. Hasil-hasil penelitian yang telah dikemukakan memunculkan peluang untuk menentukan media simpan apa yang lebih baik bila dilakukan secara bersamaan dan pada lingkungan yang sama.

\section{METODE PENELITIAN}

Penelitian dilakukan di laboratorium dasar Fakultas Pertanian Universitas Batanghari Jambi mulai tanggal 16 Januari sampai 26 April 2019. Bahan yang digunakan adalah buah kakao varietas lindak dari perkebunan rakyat di Kecamatan Kumpeh Muaro Jambi, kardus berukuran 23,5 x 15 x 11, media cocopeat, serbuk gergaji, arang sekam padi, serbuk arang kayu, abu gosok, plastik bening, bak perkecambahan (tray), air, aquadest, dan fungisida Dithane M-45. Alat-alat yang digunakan adalah timbangan analitik, pelobang kertas, besi bulat, peralatan tulis, oven listrik, termometer, jangka sorong, mikroskop, beaker gelas, dan hand sprayer.

Rancangan lingkungan yang digunakan adalah rancangan acak lengkap, sedangkan rancangan perlakuan adalah.media penyimpanan yang digunakan yaitu serbuk gergaji $\left(\mathrm{p}_{1}\right)$, cocopeat $\left(\mathrm{p}_{2}\right)$, arang sekam padi $\left(\mathrm{p}_{3}\right)$, dan serbuk arang kayu ( $\left.\mathrm{p}_{4}\right)$. Perlakuan diulang 3 kali sehingga terdapat 12 unit percobaan, setiap unit percobaan berisi 40 benih kakao. Penyimpanan benih kakao di ruang dengan suhu rata-rata $26^{\circ} \mathrm{C}$ dan kelembaban $65 \%$.

Pelaksanaan penelitian diawali dengan mendapatkan buah kakao yang masak untuk diambil bijinya 2/3 bagian (bagian tengah) dengan tujuan mendapatkan ukuran biji yang seragam. Selanjutnya biji sebagai calon benih dibersihkan dari pulpnya menggunakan abu gosok, kemudian calon benih direndam sebentar untuk melihat benih yang baik. Benih yang tenggelam di air mengindikasikan calon benih yang baik. Selanjutnya benih ditiriskan dan disortir, kemudian direndam dalam larutan fungisida 0,2\% selama 15 menit, dan calon benih dikering anginkan.

Media simpan disterilkan menggunakan oven dengan suhu $100^{\circ} \mathrm{C}$ sekitar 1 jam kemudian ditambah air aquades $50 \mathrm{ml}$ untuk menjaga kelembaban. Selanjutnya media dimasukan kedalam kardus dengan volume 1,5 gelas dengan ketebelan $\pm 3 \mathrm{~cm}$. Benih sebanyak 40 benih disimpan menggunakan kardus berukuran $23,5 \times 15 \times 11 \mathrm{~cm}$ yang diberi ventilasi $8 \%$ yang terdiri dari 35 lubang. Sebelumnya kardus telah diberi media serbuk gergaji, cocopeat, serbuk arang kayu, dan arang sekam padi yang sudah disterilkan selanjutnya kardus dimpan di ruangan suhu 24 $25^{\circ} \mathrm{C}$ selama 12 hari.

Untuk pengamatan daya kecambah benih setelah penyimpanan dilakukan perkecambahan benih sebanyak benih yang hidup pada penyimpanan. Pengecambahan benih dilakukan di bak tray yang berisi media pasir steril.

Peubahyang diamati sebagaiberikut.

1. Kadar air benih awal dan kadar air media simpan.

2. Kadar air benih setelah penyimpanan dihitung dengan menggunakan rumus $\mathrm{KA}=\frac{M 2-M 3}{M 2-M 1} X 100 \%$ Keterangan $: \mathrm{KA}=$ kadar air benih, $\mathrm{M} 1=$ berat cawan + tutup kosong , $\mathrm{M} 2=$ berat cawan + tutup + benih sebelum dipanaskan, M3 = berat cawan + tutup + benih selesai dipanaskan.

3. Persentase benih yang berkecambah dalam penyimpanan dihitung setiap 3 hari sampai hari ke 12 .

4. Persentase benih berjamur dalam penyimpanan dihitung mulai hari ke 1 sampai hari ke 12 .

5. Identifikasi jamur yang mengamati jamur yang menempel pada benih, mengambil spesimennya lalu diamati dengan mikroskop.

6. Persentase daya kecambah setelah penyimpanan 
Yulistiati Nengsih, Yuza Defitri, dan Trisna Levia. Daya Kecambah dan Kekuatan Tumbuh Benih Kakao (Theobroma cacao

$\%$ Perkecambahan $=\frac{\text { jumlah benih berkecambah normal }}{\text { jumlah benih yang dikecambahkam }} \times 100 \%$

7. Kecepatan berkecambah setelah penyimpanan. Perhitungan menggunakan rumus sebagai berikut : Kecepatan Berkecambah $=\frac{n 1}{t 1}+\frac{\mathrm{n} 2}{t 2}+\frac{\mathrm{n} 3}{t 3}+\frac{\mathrm{nx}}{t x}$

Keterangan :n adalah Jumlah benih berkecambah Tx, $\mathrm{t}$ adalah waktu diperlukan untuk berkecambah, dan $\mathrm{x}$ adalah jumlah hari

8. Panjang Kecambah $(\mathrm{cm})$. Pengukuran dilakukan pada kecambah normal hasil pengujian pada umur 7 hari.

\section{HASIL DAN PEMBAHASAN}

Sebelum dilakukan perlakuan pada benih dan media simpan, kegiatan awal yang dilakukan adalah mengukur kadar air benih, hasilnya diketahui kadar air benih awal sebesar 49,34\%, dan daya kecambah benih awal $100 \%$ artinya adalah benih dalam keadaan baik. Perlakuan pada media simpan cocopeat menunjukan persentase kadar air benih setelah penyimpanan tertinggi $(63,44 \%)$. Hal ini diduga karena media simpan cocopeat mempunyai daya serap yang tinggi, dan menyimpan air dengan baik sehingga kadar air benih setelah penyimpanan pada media serbuk cocopeat lebih tinggi. Nilai kadar air media simpan dapat dilihat padaTabel 1.

Tabel 1. Kadar Air Berbagai Media Simpan Benih Kakao dan Kadar Air Awal Benih

\begin{tabular}{clc}
\hline No. & \multicolumn{1}{c}{ Peubah } & Nilai (\%) \\
\hline 1. & Kadar Air Media Serbuk Gergaji (p1) & 22,4 \\
2. & Kadar Air Media Cocopeat(p2) & 52,2 \\
3. & Kadar Air Media Arang Sekam Padi (p3) & 37,2 \\
4. & Kadar Air Media Serbuk Arang Kayu (p4) & 31.8 \\
5. & Kadar Air Benih Awal (\%) & 49,34 \\
\hline
\end{tabular}

Tabel 1 menunjukkan bahwa kadar air media cocopeat (p2) cenderung lebih tinggi dibandingkan media lain yaitu sebesar 52,2\% dan kadar air media simpan terendah pada media serbuk gergaji (p1) sebesar 22,4\%. Sedangkan kadar air pada media arang sekam padi (p3) dan media serbuk arang kayu sebesar 37,2\% dan 31,8\%. Kadar air benih awal sebesar 49,34\% menunjukkan kondisi kadar air benih yang baik, khususnya benih rekalsitran.

Rata-rata benih berjamur, persentase daya kecambah, panjang kecambah, dan kecepatan berkecambah setelah penyimpanan dapat dilihat padaTabel 2.

Tabel 2. Rerata persentanse benih berjamur dalam penyimpanan, persentase daya kecambah, kecepatan berkecambah setelah penyimpanan dan panjang kecambah

\begin{tabular}{llcccc}
\hline & & \multicolumn{4}{c}{ Peubah } \\
\cline { 3 - 5 } No. & Media Simpan & $\begin{array}{c}\text { Benih } \\
\text { Berjamur (\%) }\end{array}$ & $\begin{array}{c}\text { Daya } \\
\text { Kecambah (\%) }\end{array}$ & $\begin{array}{c}\text { Kecepatan } \\
\text { Berkecambah } \\
\left(\text { etmal }^{-1}\right)\end{array}$ & $\begin{array}{c}\text { Panjang } \\
\text { Kecambah }(\mathrm{cm})\end{array}$ \\
\hline 1. & Serbuk gergaji (p1) & $0,85 \mathrm{a}$ & $36,27 \mathrm{ab}$ & $1,46 \mathrm{ab}^{2}$ & $4,8 \mathrm{a}$ \\
2. & Cocopeat (p2) & $1,09 \mathrm{a}$ & $34,00 \mathrm{ab}$ & $0,91 \mathrm{a}$ & $4,63 \mathrm{a}$ \\
3. & Arang sekam padi (p3) & $0,92 \mathrm{a}$ & $64,20 \mathrm{~b}$ & $2,1 \mathrm{ab}$ & $6,82 \mathrm{~b}$ \\
4. & Serbuk arang kayu (p4) & $0,79 \mathrm{a}$ & $17,50 \mathrm{a}$ & $0,63 \mathrm{a}$ & $4,01 \mathrm{a}$ \\
\hline
\end{tabular}

Keterangan : Angka-angka yang diikuti huruf kecil yang sama berbeda tidak nyata pada taraf $\alpha 5 \%$ uji lanjut DNMRT

Tabel 2 menginformasikan bahwa benih yang disimpan pada media p1, p2, p3 dan p4 memiliki kadar air yang tinggi dan cenderung meningkat dari kadar air awal benih. Hal ini diduga karena suhu di luar kardus terlalu rendah sehingga mengakibatkan terjadinya penekanan kadar air pada benih dan dapat berakibat pada penekanan perkecambahan.

Pada parameter persentase benih berjamur dalam penyimpanan menunjukkan benih yang disimpan dengan media cocopeat lebih banyak terserang jamur sebesar 23,17 \% dibanding perlakuan lainnya. Hal ini karena tingginya kadar air pada media cocopeat, hasil ini dan sejalan dengan pendapat Sutopo (2004) menyatakan bahwa kadar air yang tinggi pada media dapat mengganggu aerasi, mendorong timbulnya penyakit dan benih menjadi busuk akibat cendawan atau bakteri.

Dalam percobaan ini setiap benih berjamur dikeluarkan dari lot, diduga pada saat itu memungkinkan tertinggalnya benang-benang hifa sehingga dapat menyerang benih kakao yang masih dalam penyimpanan dan pada 
saat pengamatan dan pengambilan benih yang berjamur harus membuka sisi kardus bagian atas, diduga perlakuan pembukaan kardus memungkinkan spora-spora jamur yang ada di udara bebas masuk ke dalam kardus.

Pada parameter panjang kecambah, kecepatan berkecambah dan persentase daya kecambah setelah penyimpanan, perlakuan media arang sekam padi menunjukan hasil yang tertinggi yaitu persentase daya kecambah setelah penyimpanan sebesar 64,20\%. Panjang kecambah sebesar 6,28 cm, dan kecepatan berkecambah setelah penyimpanan sebesar 2,1 etmal ${ }^{-1}$, dibanding media simpan lainnya. Data ini bermakna, perlakuan media arang sekam padi mampu mempertahankan viabilitas benih selama penyimpanan dan dapat menahan laju metabolisme sehingga masih dapat berkecambah dengan baik setelah penyimpanan. Hal ini sejalan dengan pendapat Syaiful et.al.(2007), benih kakao yang disimpan pada media arang sekam mampu mempertahankan daya kecambahnya sebesar72,67\%. Kelembaban benih tetap terjaga dalam media arang sekam. Kondisi ini terjadi karena sifat kelengasan media arang sekam yang tinggi yakni 9,02\%, sifat tersebut mempengaruhi kemampuan sekam untuk mengikat air atau uap air.

Persentase daya kecambah setelah penyimpanan, panjang kecambah, dan kecepatan berkecambah menunjukan bahwa perlakuan menggunakan media simpan serbuk arang kayu memiliki nilai paling rendah yaitu persentase daya kecambah setelah penyimpanan sebesar 17,50\%, panjang kecambah sebesar 4,01cm, dan kecepatan berkecambah setelah penyimpanan sebesar $0,63 \mathrm{etmal}^{-1}$, hal ini diduga karena serbuk arang kayu bersifat absorban sehingga banyak menarik air pada permukaan benih, menyebabkan daya kecambah dan kecepatan berkecambah relatif lebih rendah dibandingkan dengan perlakuan lainya.

Pada pengamatan persentase benih yang bekecambah dalam penyimpanan tidak ada benih yang berkecambah, hal ini diduga karena suhu ruangan penyimpanan yang rendah. Hal ini sejalan dengan pendapat Lakitan (2004) yang menyatakan bahwa penyimpanan pada suhu rendah akitivitas metabolisme di dalam benih terhambat. Selain suhu ruang simpan, kelembaban juga mempengaruhi viabilitas benih selama penyimpanan.

Identifikasi secara mikroskopis jamur yang menyerang benih kakao dalam penyimpanan adalah jamur Aspergilus spp (Gambar 1 dan 2 )

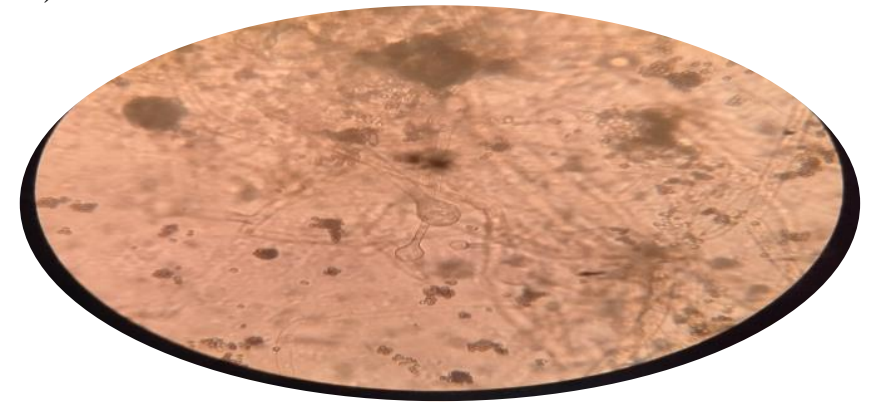

Gambar 1. Jamuryang teridentifikasi Aspergilus. Spp (menggunakan mikroskop pembesaran 10 x 40)

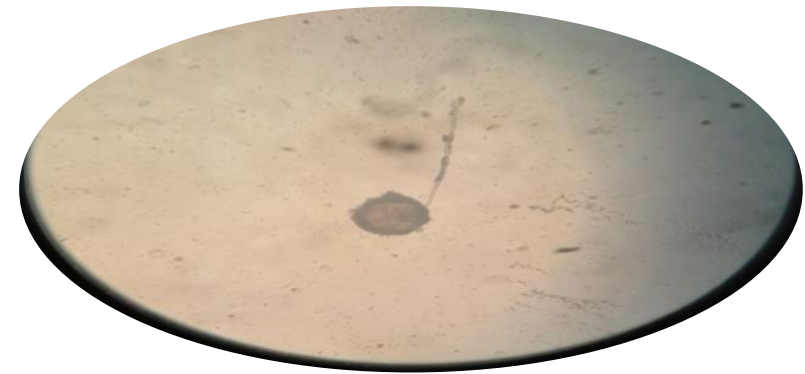

Gambar 2. Jamur yang teridentifikasi AspergilusSpp.(menggunakan mikroskop pembesaran 10 x 10)

Pada pengamatan mikroskopis jamur yang menyerang benih dalam penyimpanan adalah jamur Aspergilus spp, dengan ciri - ciri adanya hipa-hipa jamur yang berwarna putih disekitar individu benih, beberapa waktu kemudian akan berubah warna hitam, memiliki sekat di di dalam setiap hifa, dan membentuk konidia. Jamur Aspergillus bersifat kosmopolit sehingga banyak diudara dan dapat menyerang benih

\section{KESIMPULAN}

Penyimpanan benih kakao pada media arang sekam padi memberikan pengaruh nyata terhadapparameterpanjang kecambah dan kecepatan berkecambah setelah penyimpanan. Penggunaan media simpan serbuk arang kayu tidak dapat mempertahankan viabilitas benih setelah penyimpanan. Selama penyimpanan diketahui jamur yang teridentifikasi adalah jamur Aspergilus. Spp. 


\section{DAFTAR PUSTAKA}

Klimchuk,M.R,dan Krasovec, S.A.,2006. Desain Kemasan Perencanaan Merek Produk yang Berhasil Mulai Dari Konsep Sampai Penjualan. Erlangga.Jakarta

Kustantini,D dan R.Kusumastuti. 2015. Beberapa Teknik Untuk Meningkatkan Daya Simpan Benih Kakao (Theobroma cacao L.).Balai Besar Perbenihan Dan Proteksi Tanaman Perkebunan (BBPPTP).Surabaya.

Lakitan, B. 2004. Dasar-Dasar Fisiologi Tumbuhan. Raja Grafindo Persada. Jakarta

Nengsih, Y. 2018.TeknikPengemasanBenihKakaodalamPenyimpanan.Jurnal Media Pertanian.Vol 3(2) : 89-98

Rahardjo.P. 2011. Menghasilkan Benih dan Bibit Kakao Unggul.Penebar Swadaya. Jakarta

Rahardjo, P. 2012. Pengaruh Pemberian Abu Sekam Padi Sebagai Bahan Desikan Pada Penyimpanan Benih Terhadap Daya Tumbuh dan Pertumbuhan Bibit Kakao. Jurnal Pelita Perkebunan, 28 (2): 93-102.

Sumampow, F.M.D. 2011. Viabilitas Benih Kakao (Theobroma CacaoL.).Pada Media Simpan Arang Sekam Padi. Jurnal Soil Environment, 8 (3) : 102105

Sutopo,L. 2004. Teknologi Benih. Edisi Revisi. Rajawali. Jakarta.

Syaiful, S. A., M. A. Ishak dan Jusriana. 2007. Viabilitas Benih Kakao (Theobroma cacao L.) Pada Berbagai Tingkat Kadar Air Benih dan Media Simpan Benih. Jurnal Agrivigor, 6 (3) : 243-251.

Winiariyasti. 2015. Pengaruh Serbuk Arang dan Serbuk Kayu Sebagai Media Simpan Terhadap Viabilitas Benih Kakao (Theobroma cacao L.). Skripsi. Universitas Gadjah Mada Yogyakarta. 